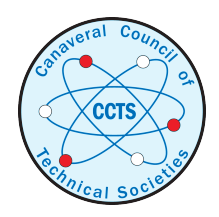

The Space Congress $®$ Proceedings

1971 (8th) Vol. 1 Technology Today And

Tomorrow

Apr 1st, 8:00 AM

\title{
Air Pollution: Our Ecological Alarm and Blessing in Disguise
}

Hugh W. Ellsaesser

Lawrence Radiation Laboratory, University of California, Livermore, California

Follow this and additional works at: https://commons.erau.edu/space-congress-proceedings

\section{Scholarly Commons Citation}

Ellsaesser, Hugh W., "Air Pollution: Our Ecological Alarm and Blessing in Disguise" (1971). The Space Congress ${ }^{\circledR}$ Proceedings. 4.

https://commons.erau.edu/space-congress-proceedings/proceedings-1971-8th/session-3/4

This Event is brought to you for free and open access by the Conferences at Scholarly Commons. It has been accepted for inclusion in The Space Congress ${ }^{\circledR}$

Proceedings by an authorized administrator of Scholarly Commons. For more information, please contact commons@erau.edu.

EMBRYRIDDLE Aeronautical University SCHOLARLY COMMONS 
AIR POLUTION; OUR ECOLDGICAL ALARM AND BLESSING IN DISGUISE

\author{
Hugh W. Ellsaesser \\ Lawrence Radiation Laboratory \\ University of California \\ Livermore, California
}

\title{
ABSTRACT
}

Air pollution is the one feedback signal of man's overgmazing of his ecological niche on the planet Earth capable of spreading an alarm throughout the encapsulated cities and suburbs and hopefully in time to allow preventive action. It has already stimilated a greater awareness of and interest in man's total enviromnent and his impact on other species. If air pollution does, indeed, anouse man to come to a planned, as opposed to a catastrophically imposed, equilibrium with the ecology of Earth no one can deny that it will truly have been a blessing in disguise.

\section{DIAGNOSIS OF OVERGRAZING}

Ain pollution is but one symptom of the underlying disease of man's overgrazing of his ecological niche. Happily it is an early symptom and one which is both comparatively innocuous and most apparent to mankind where he has most isolated himself from his ecology. Nor is it easily ignored. In fact, it is an alam system of such optimm properties that one could be persuaded to claim for it divine origin.

The diagnosis of overgrazing is not meant to imply that any absolute standand of optimm population level has been or will be exceeded but only that current growth rates cannot be maintained for even a generation without radical, and what now appear to be unsustainable, changes in the ecology of Earth. And the science of ecology tells us we cannot change any one thing. For example, building of the Aswan Dam has already been blamed for reducing the sardine catch of the eastern Mediterranean by $97 \%$, for a greatly increased rate of schistosomiasis among Egyptians ( 1 ) and for stimulating the growth of aquatic weeds which greatly increase the rate of evaporation from the lake behind the dam.

Given a finite planet and an exponential rise in global population there is no difficulty in accepting that the latter must eventually cease on force a catastrophic decline. It is then only a matter of determining a sustainable upper limit. If that linit is determined by anything other than the conscious effort of man, life near the limit is not likely to be very meaningful or pleasant for the bulk of the population.

If we restrict our attention to the more ponderable problem of overconsunption, this could presumably be rechuced by any one of the following: (1) reductian in the number of consumers (population), reduction of the consumption rate (standand of living), (3) increasing the consumption efficiency trmough use of lower grade consumables (again lower standard of living), or (4) recycling of wastes (dependent on an adequate energy supply). Extratermestrial colonization is not at present considered as a plausible alternative.

Under present social and political philosophy it appeans unlikely that oum consumer population will apply any of these palliatives with sufficient vigor to avoid a catastrophic solution imposed by the Earth's eoology itself. On the other hand it appears unthirkable that the presumed rational being, Homo sapiens, when apprised of the situation would opt for an ecologicaliy imposed solution rather than one of his own choosing.

To support the diagnosis of overgrazing there is time merely to cite some of the many problems which have emerged in recent years.

The Population Explosion; the current global doubling time is approximately 35 years.

Predictions of Widespread Famine as early as 1975.

Exhaustion of Fuel or Energy Resources; The National Acaderny of Science and National Research Council's Committee on Natumal Resources (2) concluded: when widespread industrialization is assumed, an analyeis of fuel use versus time shows that the middle $80 \%$ of the world's supply of crude oil and natural gas would be consumed during a period of 15 to 20 years and that of coal in less than a century.

Water Shortage and the associated problems of $\mathrm{Ni}-$ trate Poisoning, Salination, Thermal Pollution, Soil Erosion and Aquatic weeds.

Exhaustion of Natural Resources other than fuel and water; according to Park (3): Of the 100 minerals most important to its Industries the United States now possesses within its natural boundaries adequate supplies of only about a dozen.

Waste Disposal including Sanitary Land Fill, Ocean Dumping, Phosphates and Biodegradable Detergents, Pesticide and Herbicide Residues and now Mercury Poisaning.

And finally anthropogenic Species Anihilation by both default and design and Species Modification by selection including the species, Hom sapiens itself. 


\section{SOCIAL AND POLITICAL, PROBLEMS}

But population growth and the concomitant demands on material and energy resoumces dictated by our also rising standard of living may well not be the immediate cause of inability to sustain our consumption rate. The ever widening gap between the developed and underdeveloped countries (4) and between the affluent and impoverished members of individual countries can be expected to produce increasing bittemess as exhaustion and threatened exhaustion of planetary resources is more widely recognized. The self depletion of over-dense populations observed in nature in lenmings and in mice, and in the laboratory in rats, looms as a possibility. While the weapons of the nuclear stalemate offer a highly efficient means for accomplishing this we are not lacking in less efficient means.

In isolating himself from his natural enviromment man has langely voided the "survival of the fittest" and the associated veneration of elders. In our increasingly artificial (man-made) and humaritarian environment we have little evidence of suocess in establishing laws or overriding forces either designed to or having the effect of keeping individual success goals aligned with those of the species.

For example, we can only applaud the scientific achievements and humanitarianism of the medical profession in prolonging the lives of many for whom there would have been no hope only a few years ago. But this does not calm our apprehension for the species steming from a possibly growing pool of defective genes and the increasingly disproportionate expenditures of limited resounces on individuals whose survival is of marginal or even deterimental value to the species. In fact, that quality which we have chosen to name after ourselves, humanitarianism, may well lead to our extinction by revoking those forces which have purged our species in the past. I would like to raise the question: what is to be the factor which determines the limit to which society underwrites the cost of organ transplants and artificial organs ance technology is available to perpetuate "life" indefinitely? Since we have incapacitated our ecology's "survival of the fittest," refused to administer "the carrot and the stick," and have ample evidence of the insufficiency of "private conscience"; what remains to guide man's behavior beyond "satisfaction of his individual irmediate desires," the guiding ethic largely responsible for our current situation?

Regandless of how one feels about the problens I have cited, he must pose answers to two questions before rendering a decision. At what level will the planet's population be brought under control? Is affluence to be restricted to a small proportion of the planet's population as at present or is it to be universally shared? Denial of defensible answers to these questions is a refusal to face up to the problem.

\section{AIR POLUTION}

What has all this to do with air pollution? I see in air pollution the one ecological alam most capable of bringing man to his senses; of making him realize that if he will assume the role of God and expand his ecological niche by waging chemical and biological warfare against his fellow species and by diminishing the fossil and mineral reserves of the planet then he mast go all the way and close the ecology of his species or suffer the usual fate of a species which experiences a population bloom.

Air pollution is the symptom of overgrazing which manifests itself to us most frequently. Furthermore, unlike most of the other symptoms, it is most apparent where the bulk of us have most isolated ourselves from our natumal enviromment and while we are in the very act of adding to the pollution (being transported). Also, we now appear to be sensitized to it. If air pollution does force markind to face this problem squarely and to devise a man-made solution, no one can deny that it will have been a blessing in disguise.

Since a blessing need not in itself be benign, my argument could end here. However, I would like to make the recasting of air pollution from a scoumge to a blessing somewhat more palatable than it may appear to you now.

Despite many claims to the contrary, currently available evidence fails to confirn the contentions that we are in imminent danger of rendering our planet unfit for life due to air pollution; that air borme concentrations of the pollutants which have been of major concem in the past are steadily increasing and that substantive proof of the deleterious effects of common day to day air pollution on human health is in hand. Since I haven't time to convince you that the public has been badly misled on these three aspects of air pollution, as I believe it has, let me attempt to shock you into a reevaluation on vour own.

For that long recognized smog capital, London, England, the record (5) shows that aside from a brief respite in the early 1950 's, the atmosphere has been becoming steadily cleaner for over 80 years! Figure 1 shows the number of days per year that adverse levels of individual pollutants occured in Los Angeles between 1955 and 1968 (6). Except for $\mathrm{NO}_{2}$ no upward trend is indicated. It is important to keep in mind that during this period the population of Los Angeles County increased from about 5 million to 7 million.

What about health effects? In December 1970 there was an international conference on "Man's Health and His Air Environment" at Riverside. The only news release which I saw contained the statement: "The polluter must bear the "burden of reasonable proof of the harmlessness of his emission; the present bunden on the citizen and his public agencies to prove harm is unworkable " ". In the light of recent judicial verdicts this implies to me that the evidence that citizens are being hamned by air pollution is verv unconvincing. Published statements of exrerts including the Surgeon General of the United States confirm this $(6,7,8)$.

If this is the true state of affairs how then have we arrived at our present elaborate and increasingly 
expensive air pollution control apparatus presumably based on demonstrated health effects? Let me paint a hypothetical scenario. The literature is replete with statements that air pollution killed 63 persons in Meuse Valley in 1930, 20 in Donora Perna in 1948 and 4,000 in London in 1952. With this evidence we could quite logically conclude that a health effect exists; all we need do is demonstrate it. We therefore award research contracts to those willing to undertake the task. Those efforts which find no health effect are obviously project failures; why should we support them further or publish their results? Those projects finding at least a hint of a positive health effect are obviously on the right track. So let's refinance them to under take larger and more sensitive tests. Since positive findings of health effects merely confirm what we already lnow, there is no need to recheck the results. After a sufficient time we simply table the exposure dosages and concomitant effects and we have our air quality criteria. The fact that numen ous other exposures to equal or stronger dosages produced no detectable effects simply confuse the issue, so we omit them from consideration.

I submit that my hypothetical scenario does not differ greatly from the real one. I'm sure most of you are aware that there are reports in the literature claiming to have established direct relationships, presumed to imply cause, between air pollution and the incidence of lung cancer. Dr. John R. Goldsmith (9) of the Califormia Depariment of Health reviewed these reports, found inconsistancies and stated that the evidence failed to confin the hypothesis that community air pollution is a casual factor. A group working with Ken Watt at Davis (10) recently came to the same conclusion with regard to deaths from respiratory diseases in general and emphysema in particular in California.

In case you feel we humans are incapable of an error of the magnitude that I am suggesting, I would like to review briefly the history of ventilation on indoor air pollution $(11,12)$.

In 1668 John Mayow demonstrated that both candles and animals expired after a short time in small confined vessels due to exhaustion of "the igneoaerial particles of the air." Mayow's progress was buried by Stahl's proposal of the phlogiston theory in 1697. For 80 years the phlogiston theory was accepted and hampered progress in understanding combustion until Lavoisier discovered (or rediscovered) oxygen in 1775. Lavoisier's studies shortly lead him to conclude that not lack of oxygen but excess of carbon dioxide was the cause of discomfort and occasional diaster in occupied rooms. The following 1860 quote describes the opinion of the period and with the same emotionalism we find in much of the air pollution litenatume of todav.

"When we breathe over and over again the same air, we gradually vitiate it by the constant exhalation of carbonic acid, which gradually brings the air up to the point where the difference between it and the blood-as regards the proportions of carbonic acid-disappears. The blood ceases to be arterialized, and the vital functions are arrested. .... To place an animal in air overchanged with carbanic acid, is equivalent to a gradual prevention of his breathing at all. Suffocation results from vitiation of the air in precisely the same manner as from interception of the air. Although burking [for John Burke, executed for stangling as a means of obtaining cadavers for sale] and gagging are crimes which appal the public, that public seems almost indifferent to the milder form of the same munder when it is called 'want of ventilation'".

Lavoisier's cambon dioxide theory of bad indoor air was more than 80 years old when Max von Pettenkofer clearly demonstrated that the carbon dioxide content of badiy ventilated rooms was far below the level at which harmful effects were observed in laboratory experiments. Attention was then focused on toxic organic effluvia; termed morbific matter, kenotoxin or anthropotoxin; and detectable by odor, by darkening of sulfuric acid and potassium permanganate but otherwise unneasurable. Since these effluvia could not be measured they were assumed to be proportional to the carbon dioxide concentration which was therefore used as the measurable indicator of indoor pollution. Using this indicator, Pettenkofer derived his 1863 standard of 30 cubic feet per minute of fresh air per occupant. This standard was frozen into building codes for schools and other public buildings by Massachusetts in the $1890^{\prime} \mathrm{s}$, by New Jersey in 1903 and by Ohio and New York in 1905. In the same 1905 Flügge exorcized the anthropotoxin theory by experiments in which one subject inside a cubicle breathed fresh outside air and another subject outside the cubicle breathed air from within the cubicle. Tilese deronstrated rather conclusively that it was the cooling power (temperatume, humidity and relative movement) of the air acting on the skin which controlled comfort and ultimately survivability. Nevertheless, it was not until 40 years later in 1945 (after a struggle extending over 20 years) that New York became one of the early states to repeal the wasteful and restrictive 30-cubic-feet-per-minute law.

of the five air constituents modified by respiration; oxygen, carbon dioxide, organic effluvia, heat and misture; we required about one century each to eliminate the first three as being inconsequential. In the process we invented at least two non-existent substances; phlogiston and anthropotoxin. I should also mention the controversy surrounding downwand versus upward ventilation since carbon dioxide was supposed to be concentrated near the floor by gravitational separation; also that general acceptance of jacketed funaces was delayed by at least a century by fear of the toxic effects of "bumt air", an effect documented by an experiment in which "a bird dropped stone dead".

This brief history gives little reason for believing that 200 million Anericans (or anv other mass of humans) can't be wrong. There are many in addition to Nader's Raiders who clain we cannot afford to wait for proof before taking action against air pollution. I claim we can't afford not to wait! 


\section{CALL TO SWTTCH BATILE STANDARDS}

As a member of the species Homo sapiens, I issue the following exhortation to my fellow members:

Let us hasten not to muffle the air pollution alarm sounded by our protesting environment! Man is not yet fully awakened to the necessity for self-imposed controls to replace the ecological ones he has thus far been able to void through his technology. While other ecological alarms have sounded in the past and can be expected in the future it is too much to expect that another should be both so benign and so clearly heand by self-encapsulated man. And certainly, we can have no mone time for preventive action than by stanting today.

Stopping the growth of population has been likened to the problem of docking a great ship without ramming the pier, the onder to back engines full must be given early in the approach (13). But a more accurate picture is presented by a group of explorers traveling in a huge conveyance. Until recently the way has been uphill with many obstacles but at long last a flat crest has been passed and the craft is slowly accelerating down a steepening slope. While most are enjoying the easier and quickening pace the thought now occurs to some that the brakes have never been tested!

\section{ACKNOWLEDGEMENTS}

Work performed under the auspices of the U. S. Atomic Energy Comission. This paper was adapted from the original paper published in the March 1971 issue of EOS.

\section{REFERENCES}

(1) Hardin, G., To trouble a star: The cost of intervention in nature, Bull. Atomic Scientists, 26, 17-20, 1970.

(2) Committee on Natural Resources, Energy Resounces, Natl. Acad. Sci. - Natl. Res. Counc. Publication 1000-D, 141 pp. hashington, D. C., 1962.

(3) Park, C. F., Jr., Affluence in Jeopandy-Minerals and the Political Economy, $368 \mathrm{pp}$., Freeman, Cooper and Co, San Francisco, 1968.

(4) Blackett, P. M. S., The ever widening gap, Science, 155, 959-964, 1967.

(5) Chandler, T. J., The clinate of London, 260 pp., Hutchinson, London, 1965, P. 125.

(6) Lemke, E. E., G. Thomas and W. E. Zwiacher, Eds., Profile of Air Pollution Control in LOS Angeles County, 67 pp., Los Angeles County Air Pollution Control District, Los Angeles, 1969.

(7) Sterling, T. D., S. V. Pollack and J. J. Phair, Urban hospital morbidity and air pollution, Anch. Environ. llealth, 15, 362-374, 1967.
(8) Hamming, W. J., W. G. MacBeth and R. L. Chass, The photochemical air nollution syndrome, Arch, E Environ. Health, 14, 137-149, 1967.

(9) Goldsmith, J. R., Effects of air pollution on human health, in Air Pollution, 2nd ed., A. C. Stern, Ed., Academic Press, New York London, 1968, Vol. 1 , p. 574 .

(10) Foin, T. C., Systems ecology and the future of the human race, Systems Annalysis and Simulation. in Ecology, B. C. Patten, Ed., Vol 1, Acadenic Press, New York (in press).

(11) New York State Commission on Ventilation Ventilation, 620 p., E. P. Dutton \& Co., New York, 1923, Part I, Chapter I.

(12) Winslow, C.E.A., and L.P. Hemington, Temperature and Human Life, 278 Dp., Princeton University Press, Princeton, 1949, pp. 11-12, 168.

(13) Southerland, T. C., Jr., The battle over America's environment, Princeton Alumi Weekly, 15-24, December 9, 1969.

\section{ILUSTRATIONS}

Figure 1. Number of davs/year of adverse levels of air pollution indices in Los Angeles County 1955 to 1968. Adverse levels defined by: EI-eye irritation recorded; VSBY-visibility less than three miles and relative humidity less than $70 \%$ OXIDANT-exceeded $0.15 \mathrm{ppm}$ for 1 hour; $\mathrm{NO}_{2}$-exceeded $0.25 \mathrm{ppm}$ for 1 hour; $\mathrm{CO}$-exceeded $30 \mathrm{ppm}$ for 8 hours. Data from (6). 


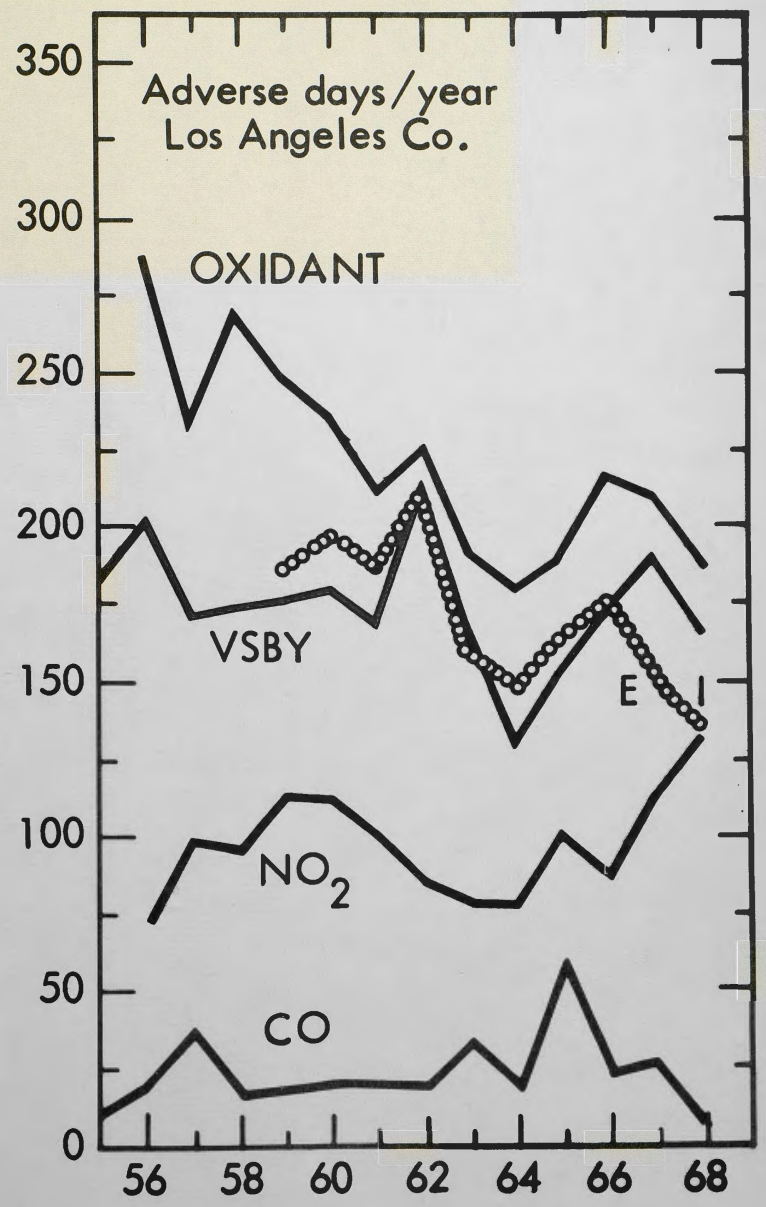

